\title{
Is Board Gender Diversity a Driver of CEO Compensation?: Examining the Leadership Style of Institutional Women Directors
}

\begin{abstract}
In this investigation, we aim at examining the influence of institutional female directors on CEO compensation. Concretely, we investigate the impact of institutional female directors as a whole, differentiating also whether institutional female directors have business ties with the firm where they sit on boards (pressure-sensitive female directors) and do not have business links (pressure-resistant female directors). We hypothesize that there is a nonlinear association, concretely quadratic, between institutional, pressure-resistant and pressuresensitive female directors on boards and CEO compensation. Our findings show that CEO compensation decreases at low levels of institutional female directors and pressure-resistant female directors on boards, but when their presence on boards increases, CEO compensation also increases. We also find that CEO compensation is not affected by pressure-sensitive female directors on boards. Hence, these findings support the premise that institutional female directors on boards cannot be considered a homogeneous group and play an important role in managerial monitoring and remuneration policies, affecting the corporate governance system.
\end{abstract}

\section{Key words}

Board gender diversity, CEO compensation, institutional women directors, pressure-sensitive women directors, pressure-resistant women directors. 


\section{Introduction}

Past research (O'Reilly \& Main, 2010; Reddy, Abidin, \& You, 2015) provides evidence that corporate governance mechanisms influence CEO compensation. Some scholars suggest that CEO compensation may help to reduce the agency conflicts between executives and shareholders (Spraggon \& Bodolica, 2011; Tosi, Werner, Katz, \& GomezMejia, 2000) and may resolve problems associated with monitoring executives (Sanders \& Carpenter, 1998).

In civil law countries like Spain, where investor protection law is weak, the main agency problem in firms is the expropriation of minority shareholders' wealth by large shareholders (Shleifer \& Vishny, 1997), board system is one-tier (all directors, non-executive and executives make up one board) and there is a high ownership concentration, listed firms are characterized by the highest presence of controlling shareholders on corporate boards, known as institutional investors, which is in contrast with the Anglo-American context, where it is less common that institutional investors appoint directors for the board. In this line, Heidrick and Struggles (2011) report that directors appointed by institutional investors account for 40 per cent of directorship in Spain, while they only account for 2 per cent of British firms' directorships. Institutional directors on boards, who represent institutional investors considered dominant shareholders, play a significant role on boards since they maximise the interests of their shareholders.

Institutional directors, due to their different capacity to connect in corporate governance and their different attitudes toward the problems of governance in firms, cannot be considered a monolithic group. In this sense, and based on Almazán, Hartzell, and Starks (2005), Chen, Harford, and Li (2007), Pucheta-Martínez and García-Meca (2014), among others, institutional directors can be differentiated between pressure-sensitive directors (they maintain business relationships with the company on whose boards they sit representing 
banks and insurance companies) and pressure-resistant directors (they have no potential business relationship with the companies in which they hold a directorship representing investment, pension and mutual funds ). Therefore, directors representing institutional investors are likely not to show a homogeneous behavior and may take different decisions, depending on the characteristics of the institutional investors they represent on boards.

Previous research also highlights the role played by gender diversity on corporate governance (Terjesen, Sealy, \& Singh, 2009), focusing on the improvement of the supervisory function and the decision-making efficiency of the board (Lucas-Pérez, MínguezVera, Baixauli-Soler, Martín-Ugedo, \& Sánchez-Marín, 2015; Nielsen \& Huse, 2010). According to past literature, institutional female directors have an important influence on earnings quality (Johnson \& Greening, 1999) and investment opportunities (Loukil \& Yousfi, 2015). However, academic literature on CEO compensation has paid little attention to female directors, and particularly institutional female directors.

Thus, the goal of this study is to analyze how institutional female directors on boards impact on CEO compensation. Furthermore, we also analyze this relationship making a distinction between pressure-sensitive institutional female directors and pressure-resistant institutional female directors.

Our paper makes several contributions to the literature. Firstly, our findings support the thesis that institutional female directors cannot be considered a uniform group in line with past literature (Almazán et al., 2005; Chen et al., 2007). Thus, this study extends previous research about the role of institutional investors in Spain, a context where the proportion of institutional investors on boards is higher than other countries such as the UK and US. Secondly, we find evidence that institutional female directors are more effective on boards than independent directors, affecting the governance system. Hence, we contribute to the corporate governance literature by demonstrating that effective institutional structures play an 
important role in managerial monitoring and remuneration policies and, thus, affect the association between institutional female directors and CEO compensation. Third, we provide empirical evidence that there is a curvilinear relationship between institutional female directors and CEO compensation. In Spanish firms, the contest hypothesis prevails when the companies are characterized by low levels of institutional female directors and pressureresistant female directors on boards, while at high levels, the collusion hypothesis prevails. Fourth, our study is, to the best of our knowledge, the first to analyze, in a Spanish context, the relationship between pressure-resistant and pressure-sensitive institutional female directors on boards and CEO compensation. This paper may be considered a tool to explain the overall relationship between Spanish institutional female directors and CEO compensation, depending on the nature of their relationships with firms, since it provides a deeper understanding of the role of institutional female directors on CEO compensation.

The Spanish setting offers a relevant opportunity to explore the impact of institutional women directors on CEO compensation, given the characteristics of the corporate governance system and the strong influence of remuneration practices between firms. The Spanish Conthe Code or Unified Code of Corporate Governance (CUBG, 2006) published in 2006, and updated in 2015 , helped to regulate or recommend the presence of female directors in decision-making bodies. To improve the low presence of female directors on boards, the Spanish parliament approved the Act 3/2007 on 22 March 2007, which called for Effective Equality between Women and Men (LOIMH, 2007), which recommended that the Spanish boards of listed companies reached a gender quota of $40 \%$ by 2015 . Given that listed firms have not yet reached this quota, the Conthe Code (CUBG, 2015) recommends that the female presence on corporate boards should be at least $30 \%$ before 2020 (see Moon, Chun, Kim, \& Kim, 2008). 
The remainder of this paper is organized as follows. After this introduction, we describe the theoretical background and hypotheses and Section 3 provides the empirical design. Section 4 describes our results, and Section 5 concludes the paper.

\section{Theoretical background and hypotheses}

Agency theory posits that the separation between the principal (shareholders) and the agent (managers and directors) of the firm generates information asymmetries between the parties, generating agency problems (Jensen \& Meckling, 1976). To mitigate agency problems, owners have used compensation policy as a mechanism to monitor executives and align their interests with those of the company (Dong \& Ozkan, 2008). Thus, companies elaborate an efficient compensation policy in order to motivate managers and directors.

The shareholders' main watchdog in the companies is the board, which is responsible for supervising the most important corporate decisions such as the design of executive remunerations (Jensen \& Murphy, 1990), and is a relevant mechanism to oversight managerial actions (Fama \& Jensen, 1983) and to improve the effectiveness of board monitoring. The non-executive directors (outside directors) will act independently from the executive directors (inside directors) and will act as good monitors for shareholders' interests (Armstrong, Guay, \& Weber, 2010). Given that managers are often driven by their selfinterests, large shareholders, such as institutional investors, can monitor managerial action, thus reducing the agency conflicts and the necessity to grant long-term incentives to align interests between managers and shareholders (Del Guercio \& Hawkins, 1999).

Institutional directors on boards have become to play an active role in monitoring managers in contrast to the passive role performed traditionally by them. Concretely, they have been considered a key mechanism to improve corporate performance (Agarwal, Erel, Ferreira, \& Matos, 2011), monitor management behavior (Del Guercio \& Hawkins, 1999) 
and control excessive compensations (Gillan \& Starks, 2000; Hartzell \& Starks, 2003). In this line, institutional directors have the motivation, expertise, resources and duty to monitor CEO compensation. Thus, institutional investors provide better governance in setting a compensation policy than do smaller investors.

Prior evidence of the impact of institutional directors on CEO compensation is mixed. Some authors (Almazán et al., 2005; Conyon, 2014) show that institutional investors reduce CEO remuneration due to the fact that they are effective in monitoring management behavior and, as a consequence, are not sensible to the management incentive problem and cannot adopt more aggressive compensation, while Balasubramanian, Barua, and Karthik (2015), Chen, Yi, and Lin (2013), Croci, Gonenc and Ozkan (2012) and Kang and Liu (2008) report a positive influence on CEO compensation, as institutional investors attempt to align the interests of CEOs and shareholders by offering high CEO compensation. Overpaid CEOs will be incentivized to do the best for the firm taking steps to increase firm value for shareholders. In this way, the interests of CEOs and shareholders will go in the same direction (e.g., Pattarin, Alon, \& Zhang, 2011).

Agency approach also argues that females on boards might monitor management team (Carter, D'Souza, Simkins, \& Simpson, 2010), reducing information asymmetries and agency costs (Wellalage \& Locke, 2013). In this respect, past literature finds women directors such as institutional female directors affect corporate performance (Pucheta-Martínez, Bel-Oms, \& Olcina-Sempere, 2016) and dividend payment (Van Pelt 2013), among others. Hence, board gender diversity may also affect executive compensation (Lucas-Pérez et al., 2015; O'Reilly \& Main, 2012).

In this sense, authors like Bugeja, Matolcsy and Spiropoulos (2016), among others, demonstrate a negative relationship between female directors on compensation committees and CEO pay. This supports the thesis that institutional female directors on boards may 
influence negatively CEO compensation because they are more risk averse in financial decision-making (Byrnes, Miller, \& Schafer, 1999), bring different perspectives to the boardroom, and develop a more trusting leadership style than men (Trinidad \& Normore, 2005). Therefore, the presence of female directors on boards reduces opportunistic behaviors and exercises greater control over CEO pay. Female directors are more rigorous in monitoring activities and may not accept an excess of executive compensation in firms. Nevertheless, there are some aspects of female directors that could increase CEO compensation. In this sense, O'Reilly and Main (2010) show that female directors are more generous and have less business experience and background than male directors; therefore, they can be convinced by CEOs to award more remuneration. According to this evidence, the presence of institutional female directors on boards may influence board decisions, such as increasing CEO compensation and, consequently, the monitoring role of female directors may be less effective. Therefore, it may support the idea that institutional female directors have a positive impact on CEO compensation because female directors may have problems with primary decision-making regarding certain issues such as executive compensation. Knott (2015), O'Reilly and Main (2010) and O'Reilly and Main (2012) find that female directors on corporate boards impact positively on CEO compensation.

Hence, whereas the monitoring hypothesis (a negative relation between institutional directors and CEO compensation) is supported by Almazán et al. (2005) and Khan, Dharwadkar and Brandes (2005), among others, the entrenchment hypothesis (a positive relation between institutional directors and CEO compensation) is evidenced by Croci et al. (2012) and Feng, Ghosh and He (2010). Nevertheless, unlike previous literature that demonstrates a linear relationship between institutional directors and CEO compensation, Brewer (1991) puts forward the theory of optimal distinctiveness, according to which, both low and high percentages of demographic features (gender diversity and institutional 
directors) within a collective (board of directors) result in more negative effects (increases in CEO compensation), while more positive effects (decreases in CEO compensation) can occur when a balanced proportion of features exists, which support a non-linear association, concretely quadratic. This suggests that the impact of group structure is probably to be nonlinear.

Consistent with this idea is the social identity approach, which posits that when a heterogeneous group interacts within a collective (a board) may affect group outcomes due to coalitions, alliances, disputes or disagreements, among others. Board gender diversity can be considered a demographic characteristic that individuals employ with the purpose of classifying themselves and others into social collectives: in-group (the same demographic collective share the board of directors) or out-group (dissimilar demographic collectives share the board of directors) members, and when individuals are out-group have more difficult to join in-group (Tajfel \& Turner, 2004). Furthermore, psychological and social identity perspectives argue that in-group individuals might consider themselves greater than outgroup individuals and, therefore, the behavior of in-group individuals in relation to out-group individuals will be unfavorable. These theoretical approaches posit that there is an interaction between the members of their own identity group rather than out-group members, since the members of intergroup are considered more trustworthy, honest and cooperative and tend to assess the competencies and abilities of their individuals more positively than the out-group members (Kramer, 1991; Tajfel, 1982). Joshi and Jackson (2003) also demonstrated that ingroup members behave in a more cooperative way because they tend to share interest and objectives. Thus, as the presence of institutional female directors increases on boards, they will make up an in-group in order to behave in a supportive way, improving intergroup cohesion and decreasing intergroup disagreement. This constructive intergroup interaction may impact negatively on CEO pay (positive outcome). 
However, cooperative behaviors among directors may change to competitive behaviors and, as a consequence, might appear conflicts when directors are classified as in- or out-group (Joshi \& Jackson, 2003). The differences between groups may generate negative behaviors in members of a low-status group (gender diversity or ethnic minorities) about their collective identity (Hornsey \&d Hogg, 1999). These adverse behaviors cause problems in the in-group interactions and, consequently, it may lead to a decrease of firm value or an increase in CEO compensation. Thus, there will be a tipping point that will change the correlation of internal aspects of the board, causing the intergroup conflict of board members to have an influence (Ali, Ng, \& Kulik, 2014). Beyond this critical point, the addition of more institutional female directors within the same group (boards) with different personalities and social competences could cause divergent processes and dissatisfaction with the organization, resulting in a negative outcome (increases on CEO pay).

We extend this view to the relationship between institutional women directors and CEO compensation. Thus, as the proportion of institutional female directors on boards augments, CEO compensation will reduce (positive consequence), but when the presence of institutional female directors exceeds a certain threshold, the inclusion of additional institutional women directors on boards will increase CEO pay (negative consequence). Consequently, this premise suggests that there is a non-linear association, concretely curvilinear, between institutional women directors and CEO remuneration.

Prior research, to the best of our knowledge, has not hypothesized a non-linear relationship between institutional female directors and CEO pay. Hence, based on the above arguments and extending them to board gender diversity, we expect a non-linear relationship between institutional women directors on boards and CEO compensation and, accordingly, we pose the following hypothesis: 
H1: CEO pay is negatively affected by institutional women directors on boards, but when their presence on boards exceeds a certain threshold, CEO pay is positively affected.

Past research shows that institutional directors are a key mechanism that influences the decision-making bodies, but not all are equally willing or able to serve this function (Almazán et al., 2005). Accordingly, this evidence argues that business relationships with the company on whose boards they sit may have an effect on the preferences and incentives of the institutional directors to control corporate decisions. Thus, institutional directors cannot be considered a uniform group, owing to their different incentives, abilities and attitudes to engage in corporate governance (Almazán et al., 2005; Cornett, Marcus, Saunders, \& Tehranian, 2007; Jara-Bertín, López-Iturriaga, \& López de Foronda, 2012; López-Iturriaga, García-Meca, \& Tejerina-Gaite, 2015). Along with this line, most authors identify two groups of directors, according to their business goals: pressure-sensitive and pressure-resistant institutional directors (Bhattacharya \& Graham, 2007; Dong \& Ozkan, 2008).

Pressure-sensitive institutional directors (banks and insurance companies) represent investors who have existing or potential business ties with firms where they invest. They attempt to do business with firms; therefore, they are subject to managerial pressure and have limitations in monitoring the organizations. On the other hand, pressure-resistant institutional directors (mutual funds, investment funds, pension funds, and venture capital firms) have no business links with firms where their represented invest. They do not face any monitoring obstacles, have a more independent position in the firm, and can successfully monitor corporate managers (Jara-Bertín et al., 2012; Pucheta-Martínez \& García-Meca, 2014).

Pressure-sensitive institutional directors may lack the incentives or ability to effectively monitor managers, although they can mitigate agency conflict through higher levels of executive compensation (Almazán et al., 2005; Khan et al., 2005). As mentioned before, increases of CEO pay may result in a better firm performance and, thus, both 
shareholders and managers might align their interests. Pressure-sensitive investors are in a dependent position from the companies since they maintain commercial ties and, therefore, they will be likely to increase CEO compensation in order to keep and secure their business ties (David, Kochar, \& Levitas, 1998). They have strict fiduciary standards and prefer shortterm earnings, so they prefer to invest in short-term horizons. López-Iturriaga et al. (2015) and Shin and Seo (2011) report a positive association between pressure-sensitive institutional directors and CEO compensation. However, when pressure-sensitive institutional directors reach a certain level, they could develop a more active role in the governance of firms, which could negatively affect CEO compensation. In this case, large shareholders, like banks or insurance companies, could create coalitions between them in order to take out private benefits (Jara-Bertín, López-Iturriaga, \& López de Foronda, 2008). Thus, as there is a greater presence of pressure-sensitive directors on boards, they might be interested in preventing agreements between themselves and CEOs because, when they act as shareholders and lenders, they may perform more monitoring activities (De Andrés, Azofra, \& Tejerina, 2010) in order to mitigate the opportunistic behavior of the new controlling shareholders (MahrtSmith, 2006). According to the above arguments, as the presence of pressure-sensitive institutional directors on boards grows, the monitoring role played by them to contest the power of other large shareholders also grows (Gomes \& Novaes, 2005) and, therefore, it may be used to monitor CEO decisions and to prevent the CEO from colluding with other pressure-sensitive institutional directors. Consequently, pressure-sensitive institutional directors may be more likely to decrease CEO compensation. In this line, the combination of the collusion and contest hypotheses may support a nonlinear relationship between pressuresensitive institutional directors and CEO compensation. This quadratic relationship is supported by De Andrés et al. (2010) and Morck, Nakamura and Shivdasani (2000), who examined the association between pressure-sensitive institutional ownership and corporate 
performance. As addressed in the institutional directorship hypothesis, we can draw on the theory of optimal distinctiveness of Brewer (1991) to give a stronger support to the nonlinear correlation between pressure-sensitive women directors and CEO pay.

Pressure-resistant institutional directors are less likely to suffer from conflicts of interest arising from business relationships, and can serve as a monitoring mechanism in mitigating agency problems between shareholders and managers (Bhattacharya \& Graham, 2007; Cornett et al., 2007). In this vein, they have a long-term horizon and, therefore, prefer to invest in firms with an international strategy (Tihanyi, Johnson, Hoskisson, \& Hitt, 2003). Thus, pressure-resistant institutional directors on boards are more likely to actively be involved in monitoring, and may influence CEO pay by reducing total compensation (LópezIturriaga et al., 2015). David et al. (1998), Dong and Ozkan (2008) and Shin and Seo (2011) demonstrate a negative association between pressure-resistant institutional ownership and CEO compensation. Nevertheless, Chowdhury and Wang (2009) find a positive relationship between pressure-resistant institutional investors and CEO compensation. According to this evidence, pressure-resistant investors may be less efficient in the monitoring role and, therefore, CEOs may achieve more control in the determination of his/her compensation. Thus, extending the arguments discussed in the first hypothesis to pressure-resistant female directors, the relation between them and CEO compensation will be negative to some extent, but when pressure-resistant female directors reach a certain point, both interest conflicts and coordination problems may appear between pressure-resistant female directors, which may be exploited by CEOs to obtain, for example, greater compensation. Given that we expect the same behavior for pressure-resistant female directors than for institutional female directors as a whole, a deeper explanation for the nonlinear association, particularly quadratic, between pressure-resistant women directors and CEO pay can be found in the hypothesis focused on institutional women directors, based on Brewer's approach (1991). 
To our best knowledge, there is no previous evidence that examines the effect that pressure-resistant and pressure-sensitive female directors on boards have on CEO compensation. Thus, based on the above arguments, we predict a nonlinear relationship, concretely quadratic, between pressure-resistant and pressure-sensitive institutional female directors on boards and CEO pay. Thus, we posit the following hypotheses:

H2: CEO pay is positively affected by pressure-sensitive women directors on boards, but when their presence on boards exceeds a certain threshold, CEO pay is negatively affected.

H3: CEO pay is negatively affected by pressure-resistant women directors on boards, but when their presence on boards exceeds a certain threshold, CEO pay is positively affected.

\section{Empirical Design}

\section{Sample}

The study is based on the total population of non-financial listed firms in Spain for the period from 2010 to 2014. Financial companies have been excluded both because they are under special scrutiny by financial authorities that constrain the role of their board of directors and because of their special accounting practices. The data were collected from the Public Register of the Spanish Securities Market Commission (CNMV), from the "Sistemas de Análisis de Balances Ibéricos" (SABI) database and corporate governance and directors' remuneration reports that companies have had to disclose annually since 2003 and 2011, respectively. The annual reports disclose the data for two consecutive years.

We have built an unbalanced panel of 553 firm-year observations. Nevertheless, the estimations based on unbalanced panels are as reliable as those based on balanced panels (Arellano, 2003). 


\section{Variables}

The dependent variable CEO compensation is defined as CEO_COMP, and is calculated as the natural logarithm of CEO's total compensation, which includes salary, allowances, compensation for attending committees and any other monetary benefits including stock options. Authors such as Croci et al. (2012) and Reddy et al. (2015), among others, have also employed the logarithm of CEO's total compensation.

We have also used several independent variables. The percentage of institutional female directors is defined as INST_WOM. We define SENSIT_WOM as the proportion of female directors who are representative of pressure-sensitive institutional investors and RESIST_WOM as the proportion of female directors who are representative of pressureresistant institutional investors. INST_WOM ${ }^{2}$, SENSIT_WOM ${ }^{2}$ and RESIST_WOM ${ }^{2}$ are defined as the square of the proportion of institutional female directors on boards, of the proportion of pressure-sensitive institutional female directors and pressure-sensitive institutional investors and of the proportion of pressure-resistant institutional female directors (Navissi \& Naiker, 2006), respectively.

We control for a set of governance and financial variables that could have a significant impact on CEO compensation: when the chairperson of the board and CEO are the same person (CEO_DUALITY), the length of time for which the CEO has performed this role (CEO_TENURE), board independence (INDP), management ownership (OWNMAN), profitability (ROA), firm size (SIZE), the leverage of level of the firms (LEV) and two dummy variables in order to control whether there is a systematic difference between pressure-sensitive and pressure-resistant women directors (DUM_FEM_SENSIT and DUM_FEM_RESIST). Finally, we also consider year and firm fixed effects to control for year- and firm-specific effects on CEO compensation. A summary of all the variables is provided in Table 1. 
Insert Table 1 about here>

\section{Results}

\section{Descriptive statistics}

Table 2 presents the mean, the median, the standard error, and the 10th and 90th percentiles of the main variables. As can be seen in Table 2, CEO compensation is, on average, 4.252 (the natural logarithm of a CEO's total compensation expressed in Euros). Institutional female directors account for $7.85 \%$, pressure-sensitive institutional female directors represent $2.59 \%$ and pressure-resistant institutional female directors $5.26 \%$. The proportion of independent directors on the boards is, on average, $33.38 \%$, manager ownership represents $27.73 \%$, CEO duality accounts for $32 \%$ and CEO tenure, on average, is 1.71 years. The return on assets is $-1.45 \%$, the level of leverage is, on average, $57.33 \%$ and the mean size of the firm is 13.053 ( $\log$ of the total assets).

<Insert Table 2 about here>

To test for multicollinearity, we have calculated the Pearson correlation matrix. However, for the sake of brevity, the findings are not reported. The correlation between most pairs is low, generally below 0.3 . Thus, we conclude that multicollinearity is not a problem.

\section{Multivariate analysis}

Table 3 offers the results of the linear regression for institutional, pressure-sensitive and pressure-resistant female directors on boards. As can be observed, we built three models.

<Insert Table 3 about here>

In Model 1, the variable denoting institutional female directors on boards in linear (INST_WOM) and nonlinear ways $\left(\right.$ INST_WOM $^{2}$ ), concretely quadratic, presents the expected signs and is statistically significant. Therefore, we cannot reject the hypothesis 1 , since the proportion of institutional female directors impacts negatively CEO compensation, but when the percentage of institutional female directors reaches a certain level, it is 
positively affected. This quadratic relation is supported by two opposite premises: institutional female directors may monitor decisions and activities in order to reduce CEO compensation (e.g., Firth, Fung, \& Rui, 2007; Ning, Hu., \& Garza-Gómez, 2015; SánchezMarín, Baixauli-Soler, \& Lucas-Pérez, 2011), but when their presence on boards reaches a certain threshold, they may collude with CEOs, increasing CEO compensation (Croci et al., 2012; Fernandes, Ferreira, Matos, \& Murphy, 2012). Thus, consistent with our results, previous research also supports a non-linear relation between institutional directors and firm performance; therefore, this evidence suggests that, at low levels, the contest hypothesis prevails, since institutional female directors reduce CEO compensation. However, at high levels, the collusion hypothesis prevails, since they may work with CEOs to achieve their own aims and, therefore, they will be more proactive to increase CEO compensation. Contrary to our predictions, and as shown in Model 2, the variable pressure-sensitive institutional female directors on boards presents a linear (SENSIT_WOM) and nonlinear $\left(\mathrm{SENSIT}_{\mathrm{W}} \mathrm{WOM}^{2}\right)$ relation, exhibiting the non-expected signs. Additionally, they are not statistically significant and, consequently, we cannot accept the hypothesis 2 . This finding suggests that, contrary to our predictions, CEO compensation does not grow with increases in pressure-sensitive institutional female directors on boards up to a point, beyond which, further increases in pressure-sensitive institutional female directors are not associated with decreases in CEO compensation.

In Model 3, we observe that the variables representing pressure-resistant institutional female directors on boards, in linear (RESIST_WOM) and nonlinear (RESIST_WOM²) ways, provide the expected signs and are statistically significant. Thus, the third hypothesis cannot be rejected. This result supports the notion that the proportion of pressure-resistant institutional female directors affects negatively CEO compensation, but when the proportion of pressure-resistant institutional female directors reaches a certain level, they have a positive 
effect on CEO compensation. Under this assumption, we extend the literature regarding pressure-resistant female directors and CEO compensation. Concretely, a moderate level of pressure-resistant female directors on corporate boards reduces CEO compensation, whereas an excessive presence of pressure-resistant female directors on boards increases CEO pay. This result is also supported by Jara-Bertín et al. (2012), Jiao and Ye (2013) and Navissi and Naiker (2006), who demonstrate a non-linear relationship between pressure-resistant institutional directors and firm performance.

Regarding the control variables, we can observe that duality in the position of CEO and chairperson of the board (CEO_DUALITY), tenure of CEO (CEO_TENURE), ownership of managers (OWNMAN), firm size (SIZE) and leverage (LEV) present a positive sign, as predicted, and they are statistically significant. The rest of control variable are insignificant.

We have also considered endogeneity concerns between institutional female directors and CEO compensation. This matter is addressed by lagging the independent variables. The findings, unreported by the sake of the brevity, are consistent with our main findings.

\section{Analysis extension}

The difficult situation in Spain has led to listed firms to report losses and, consequently, it is likely that companies with losses do not increase CEO compensation. Then, in the analysis extension, we remove from the sample companies that report a negative return on assets (ROA) in the period of analysis. A positive ROA is an indicator of a better firm performance, which may result in an increase of CEO remuneration since a higher firm performance can be the outcome of the best management of the CEO, its effort and its talent (Gabaix \& Landier, 2008). These arguments are consistent with theories focused on the interaction between company scale and the demand for CEO talent, getting the most determined empirical support in the associated increases in firm performance and CEO 
compensation. In this line, Faria, Martins and Brandão (2014) find that as firm performance (measured as ROA) enhances, CEO compensation is also higher.

The findings, not provided for the sake of brevity, show that institutional female directors on boards influence CEO compensation when their presence reaches a higher level, but not when their proportion on the board is low. Furthermore, the findings also reveal that CEO compensation decreases at low levels of pressure-resistant institutional female directors, but when their presence reaches a certain threshold, further increases in pressure-resistant institutional female directors are associated with increases in CEO compensation. On the other hand, the results also demonstrate that the proportion of pressure-sensitive institutional female directors does not impact CEO pay at any level: low and high. The same analysis has been conducted removing companies that report a positive return on assets in the period examined. According to the findings, institutional female directors, pressure-resistant and pressure-sensitive institutional female directors behave in the same way as when the companies report profits. Hence, these results suggest that the financial crisis does not significantly impact the relationship between institutional, pressure-sensitive and pressureresistant female directors on Spanish boards and CEO compensation.

\section{Conclusions}

Little attention has been paid to the role of institutional female directors on boards on CEO compensation. Thus, the aim of this study is twofold. First, we examine the impact of institutional female directors as a whole on boards on CEO compensation. Second, we analyse this relationship, differentiating between pressure-sensitive institutional female directors and pressure-resistant institutional female directors.

Our study provides evidence that institutional female directors play an important role as a mechanism of corporate governance. Concretely, our paper demonstrates that institutional female directors considered a whole and pressure-resistant female directors 
(represent institutional investors who do not maintain commercial ties with the firm where they sit on boards) affect negatively CEO compensation, but when they reach a certain level, CEO compensation increases. This finding suggests that as the presence of institutional and pressure-resistant women directors on boards increases, CEO pay decreases, in line with the monitoring hypothesis. Thus, board structures with low presence of institutional and pressure-resistant female directors become an effective mechanism for monitoring CEO pay, controlling management team decisions that may benefit it and, therefore, they will not align with management decisions regarding pay. However, when the presence of institutional and pressure-resistant women directors reaches a critical point, the adding of more institutional and pressure-resistant female directors on boards will enhance CEO pay, consistent with the entrenchment hypothesis. Therefore, a higher proportion of institutional and pressureresistant female directors may imply an entrenchment and, thereby, they will support managerial decisions, particularly those relative to compensations. Consequently, board structures with higher proportions of institutional women directors become an ineffective mechanism for controlling CEO compensation and, thus, they will serve as a device to encourage pay. Our results also demonstrate that CEO compensation is not affected by the proportion of pressure-sensitive female directors on boards. Thus, the presence of pressuresensitive institutional female directors cannot be considered a significant monitoring mechanism to influence CEO compensation since they support neither increases nor decreases on it. This result is contrary to the view that pressure-sensitive female directors would be willing to preserve the commercial relations that their represented maintain with the firm where they hold a directorship and, as a result, neither the collusion nor the monitoring hypotheses prevail for pressure-sensitive female directors when they have to make a decision about CEO pay. The lack of relevant impact of pressure-sensitive institutional female directors on CEO pay may be explained by various reasons. First, pressure-sensitive women 
directors are representing mainly institutional investors such as banks and insurance companies with aims different from those of the remainder of institutional investors. As a consequence, their incentives, motivations and abilities to oversee CEO compensation might not be consistent with those of other institutional investors (Shin \& Seo, 2011). Second, pressure-sensitive institutional female directors might be more involved in issues relative to designing of corporate strategies and finding solutions to problems rather than aligning with management team or monitoring management team. Third, the specific composition of pressure-sensitive institutional female directors (e.g., represent banks and insurance companies) is likely to become more transient investors. Thus, these directors might be influenced by the governing bodies in the firm's strategic decisions. Finally, pressuresensitive institutional women directors may be more interested in not using CEO pay as a corporate governance mechanism for controlling or aligning with managers, but others governance tools, which suggests that corporate governance mechanism are replaceable.

Our results have different implications for the corporate governance debate. First, the results obtained should be useful as an empirical guide for Spanish policymakers, regulators, and corporate decision makers concerning female directors. The incorporation of women onto boards promotes gender equality and increases the effectiveness of the board by creating diversity in the decision-making process. Second, the most important policy implication of our study is that, in the current weak corporate governance in Spain, female directors affect remuneration policies. Therefore, our results should encourage policymakers to promote a more efficient corporate system through the incorporation of female directors. Third, another implication that can be derived from this analysis is that institutional female directors cannot be considered a homogeneous group because, when they are considered as a whole, they behave in one way regarding CEO pay, but when we distinguish them between pressuresensitive and pressure-resistant female directors, they do not behave in the same way. Thus, 
companies should revisit the presence of institutional female directors on boards. Our findings are relevant for European countries characterized by weak corporate governance, where the most predominant agency conflict is the expropriation of minority shareholder's wealth by large shareholders. Finally, our results also have practical implications for managers, shareholders and the remainder of stakeholders since they show that a low or high proportion of institutional, pressure-resistant and pressure-sensitive women directors on boards will determine what board structure is more or less effective mechanism for monitoring CEO pay. Board structures made up by low proportions of institutional and pressure-resistant women directors females directors act as an effective corporate governance mechanism for controlling CEO pay because they will reduce it, while high percentages of institutional and pressure-resistant women directors female directors result in ineffective device for monitoring CEO compensation since they will enhance it. On the other hand, board structures with pressure-sensitive female directors do not have an effect on CEO pay and, therefore, one implication of this finding is that their presence on boards may be neither effective nor ineffective corporate governance mechanism concerning CEO compensation. Beyond the prior findings, past research also recognizes that women's presence on corporate boards has direct effect on CEO compensation and, consequently, on the corporate governance field. In this sense, female leadership style is characterized by women more sympathetic, civilized, conservative, stricter, democratic and sensitive, among others, which may help firms in the decision-making process of firms affecting, for instance, CEO remuneration, which may result in a better corporate governance.

The limitations of this study are the following. Firstly, the proportion of institutional female directors on boards is limited in Spanish companies, despite recommendations and LOIMH (2007). Secondly, this study is based on the Spanish listed firms from 2010 to 2014. Our sample excludes industrial companies before 2010 because Spanish listed firms were not 
obligated to publish the remunerations of the directors until 2011 (disclosing also the data of the previous year, 2010). Thirdly, it is possible that there are unknown factors that could affect our dependent variable. While we have controlled for as many factors as possible based on theory and previous research, empirical and theoretical limitations prevent us from knowing whether all of the important influences have been controlled for and addressed.

We also suggest the following future research avenues. Researchers may study the repercussions of institutional female directors on CEO compensation comparing boards and remuneration committees.

\section{References}

Act 3/2007, of 22 March, for Effective Equality between Women and Men.

Agarwal, R., Erel, I., Ferreira, M., \& Matos, P. (2011). Does governance travel around the world? Evidence from institutional investors. Journal of Financial Economics, 100(1), 154-181. DOI :10.1016/j.jfineco.2010.10.018

Ali, M., Ng, Y. L., \& Kulik, C. (2014). Board age and gender diversity: A test of competing linear and curvilinear predictions. Journal of Business Ethics, 125(3), 497-512. DOI: $10.1007 / \mathrm{s} 10551-013-1930-9$

Almazán, A., Hartzell, J. C., \& Starks, L. T. (2005). Active institutional shareholders and costs of monitoring: evidence from executive compensation. Financial Management, 34(4), 5-34. DOI: 10.1111/j.1755-053X.2005.tb00116.x

Arellano, M. (2003). Panel data econometrics. Oxford: Oxford University Press.

Armstrong, C. S., Guay, W. R., \& Weber, J. P. (2010). The role of information and financial reporting in corporate governance and debt contracting. Journal of Accounting \& Economics, 50 (2/3), 179-234. DOI: 10.1016/j.jacceco.2010.10.001

Balasubramanian, B. N., Barua, S. K., \& Karthik, D. (2015). Influence of Board Diversity and Characteristics on CEO Compensation: Contingent Effects of Concentrated Ownership (No. WP2015-03-37). Indian Institute of Management Ahmedabad, Research and Publication Department. Indian Institute of Management, Ahmedabad.

Bhattacharya, P. S., \& Graham, M. (2007). Institutional ownership and firm value: evidence from Finland?, Working Paper, School of Accounting, Economics and Finance, Faculty of Business and Law, Deaking University, Melbourne. 
Brewer, M. B. (1991). The social self: On being the same and different at the same time. Personality and Social Psychology Bulletin, 17(5), 475-482.

Bugeja, M., Matolcsy, Z., \& Spiropoulos, H. (2016). The association between gender-diverse compensation committees and CEO compensation. Journal of Business Ethics, 139(2), 375-390. DOI: 10.1007/s10551-015-2660-y

Byrnes, J., Miller, D., \& Schafer, W. (1999). Gender Differences in Risk Taking: A Metaanalysis. Psychological Bulletin, 125(3), 367-383.

Carter, D. A., D'Souza, F., Simkins, B. J., \& Simpson, W. G. (2010). The gender and ethnic diversity of US boards and board committees and firm financial performance. Corporate Governance: An International Review, 18(5), 396-414. DOI: 10.1111/j.1467-8683.2010.00809.x

Chen, X., Harford, J., \& Li K. (2007). Monitoring: which institutions matter?. Journal of Financial Economics, 86, 279-305. DOI: 10.1016/j.jfineco.2006.09.005

Chen, C. W., Yi, B., \& Lin, J. B. (2013). Media coverage, board structure and CEO compensation: Evidence from Taiwan. Journal of Multinational Financial Management, 23(5), 434-445. DOI: https://doi.org/10.1016/j.mulfin.2013.08.003

Chowdhury, S. D., \& Wang, e.z. (2009). Institutional activism types and CEO compensation: A time-series analysis of large Canadian corporations. Journal of Management, 35(1), $5-36$.

Conyon, M. J. (2014). Executive compensation and board governance in US firms. The Economic Journal, 124(574), 60-89. DOI: 10.1111/ecoj.12120

Cornett, M. M., Marcus, A. J., Saunders, A., \& Tehranian, H. (2007). The impact of institutional ownership on corporate operating performance. Journal of Banking \& Finance, 31(6), 1771-1794. DOI: 10.1016/j.jbankfin.2006.08.006

Croci, E., Gonenc, H., \& Ozkan, N. (2012). CEO compensation, family control and institutional investors in continental Europe. Journal of Banking \& Finance, 36, 3318-3335. DOI: http://dx.doi.org/10.1016/j.jbankfin.2012.07.017

David, P., Kochar, R., \& Levitas, E. (1998). The Effect of Institutional Investors on the Level and Mix of CEO Compensation. Academy of Management Journal, 41(2), 200-208. DOI: $10.2307 / 257102$

De Andrés, P., Azofra, V., \& Tejerina, F. (2010). The bank: controller or predator in the governance of nonfinancial firm?. Investment Management and Financial Innovation, 7(1), 24-36. 
Del Guercio, D., \& Hawkins, J. (1999). The motivation and impact of pension fund activism. Journal of Financial Economics, 52(3), 293-340. DOI: S 0304 - 405 X ( 99 ) 00 $011-2$

Dong, M., \& Ozkan, A. (2008). Institutional investors and director pay: an empirical study of UK companies. Journal of Multinational Financial Management, 18(1), 16-29. DOI: 10.1016/j.mulfin.2007.06.001

Fama, E. F., \& Jensen, M. C. (1983). Agency Problems and Residual Claims. The Journal of Law and Economics, 26(2), 327-349.

Faria, P., Martins, F. V., \& Brandão, E. (2014). The level of CEO compensation for the short and long-term -a view on high-tech firms. Procedia - Social and Behavioral Sciences 110, 1023-1032. DOI: 10.1016/j.sbspro.2013.12.949

Feng, Z., Ghosh, C., \& He, F. (2010). Institutional monitoring and REIT CEO compensation. The Journal of Real Estate Finance and Economics, 40(4), 446-479. DOI: $10.1007 / \mathrm{s} 11146-009-9216-9$

Fernandes, N. G., Ferreira, M. A., Matos, P. P., \& Murphy, K. J. (2012). Are U.S. CEOs Paid More? New International Evidence. The Review of Financial Studies, 26(2), 323-367. DOI: $10.1093 / \mathrm{rfs} / \mathrm{hhs} 122$

Firth, M., Fung, P. M., \& Rui, O. M. (2007). How ownership and corporate governance influence chief executive pay in China's listed firms. Journal of Business Research, 60 (7), 776-785. DOI: 10.1016/j.jbusres.2007.01.014

Gabaix, X. \& Landier, A. (2008). Why has CEO pay increased so much?. The Quarterly Journal of Economics, 123(1), 49-100. DOI: 10.1162/qjec.2008.123.1.49

Gillan, S., \& Starks, L. (2000). Corporate governance proposal and shareholder activism: the role of institutional investors. Journal of Financial Economics, 57(2), 275-305. DOI: $10.1016 / \mathrm{S} 0304-405 \mathrm{X}(00) 00058-1$

Gomes, A., \& Novaes, W. (2005). Sharing of control versus monitoring as corporate governance mechanism. Working paper num. 01-029. Penn Institute for Economic Research (PIER)/Institute for Law and Economics research paper num. 01-12. Available at: http://papers.ssrn.com/sol3/papers.cfm?abstract_id=277111

Hartzell, J. C., \& Starks, L. T. (2003). Institutional investors and executive compensation. Journal of Finance, 58(6), 2351-2374. DOI: 10.1046/j.1540-6261.2003.00608.x

Heidrick \& Struggles Report (2011). Challenging board performance. European Report on Corporate Governance: Heidrick \& Struggles. 
Hornsey, M. J., \& Hogg, M. A. (1999). Subgroup differentiation as a response to an overlyinclusive group: A test of optimal distinctiveness theory. European Journal of Social Psychology, 29(4), 543-550. DOI: 10.1002/(SICI)1099-0992(199906)29:4<543::AIDEJSP945>3.0.CO;2-A

Jara-Bertín, M., López-Iturriaga, F., \& López de Foronda, O. (2008). The contest to the control in European family firms: How other shareholders affect firm value? Corporate Governance: an International Review, 6(3), 146-159. DOI: 10.1111/j.1467-8683.2008.00677.x

Jara-Bertín, M., López-Iturriaga, F., \& López-de-Foronda, O. (2012). Does the influence of institutional investors depend on the institutional framework? An international analysis. Applied Economics, 44(3), 265-278. DOI: 10.1080/00036846.2010.502112

Jensen M. C., \& Meckling W. H. (1976). Theory of the firm: managerial behaviour, agency cost and ownership structure. Journal of Finance Economics, 3(4), 305-360. DOI: $10.1016 / 0304-405 X(76) 90026-X$

Jensen M. C., \& Murphy, K. J. (1990). Performance and top management incentives. Journal Politic Economic, 98(2), 225-264. DOI: 10.1086/261677

Jiao, Y., \& Ye, P. (2013). Public pension fund ownership and firm performance. Review of Quantitative Finance and Accounting, 40(3), 571-590. DOI: 10.1007/s11156-0120288-x

Johnson, R. A., \& Greening, D. W. (1999). The effects of corporate governance and institutional ownership types on corporate social performance. Academy of Management Journal, 42(5), 564-576. DOI: 10.2307/256977

Joshi, A., \& Jackson, S.E. (2003). Managing workforce diversity to enhance cooperation in organizations. In West, M.A., Tjosvold, D. and Smith, K. (2003). International handbook of organizational teamwork and cooperative working, 277 - 296, New York: John Wiley \& Sons.

Kang, Q., \& Liu, Q. (2008). Stock trading, information production, and executive incentives. Journal of Corporate Finance, 14(4), 484-498. DOI: 10.1016/j.jcorpfin.2008.06.003

Khan, R., Dharwadkar, R., \& Brandes, P. (2005). Institutional ownership and CEO compensation: a longitudinal examination. Journal of Business Research, 58(8), 1078-1088. DOI: 0.1016/j.jbusres.2004.02.002

Knott, D. M. (2015). Friends in High Places: Measuring the Effects of Compensation Committee Characteristics on CEO Pay Packages in 2013. Doctoral dissertation, 
Claremont McKenna College). Available from CMC Senior Theses. 1050. http://scholarship.claremont.edu/cmc_theses/1050

Kramer, R. M. (1991). Intergroup relations and organizational dilemmas-The role of categorization processes. Research in Organizational Behavior, 13, 191-228

Loukil, N., \& Yousfi, O. (2015). Does gender diversity on corporate boards increase risktaking?. Canadian Journal of Administrative Sciences, 33(1), 66-81. DOI: 10.1002/cjas. 1326

López-Iturriaga, F., García-Meca, E., \& Tejerina-Gaite, F. (2015). Institutional directors and board compensation: Spanish evidence. BRQ Business Research Quarterly, 18(3), 161-173. DOI: 10.1016/j.brq.2014.07.003

Lucas-Pérez, M. E., Mínguez-Vera, A., Baixauli-Soler, J. S., Martín-Ugedo, J. F. \& SánchezMarín, G. (2015). Women on the board and managers' pay: Evidence from Spain. Journal of Business Ethics, 129(2), 265-280. DOI: 10.1007/s10551-014-2148-1

Mahrt-Smith, J. (2006). Should banks own equity stakes in their borrowers?. A contractual solution to hold-up problems. Journal of Banking \& Finance, 30(10), 2911-2929. DOI: 10.1016/j.jbankfin.2005.12.003

Moon, K-H., Chun, K-O., Kim, M-S., \& Kim, E-K. (2008). A Comparative Study of Electoral Gender Quotas in Sweden, Germany, and South Korea: Focusing on the Interplay of the Main Actors in the Processes of the Implementation of Quota Policies. Asian Women, 24(1), 75-100.

Morck, R., Nakamura, M., \& Shivdasani, A. (2000). Banks, Ownership Structure, and Firm Value in Japan. The Journal of Business, 73(4), 539-567. OI: 10.1086/209654

Navissi, F., \& Naiker, V. (2006). Institutional ownership and corporate value. Managerial Finance, 32(3), 247-256. DOI: 10.1108/03074350610646753

Nielsen, S. T., \& Huse, M. (2010). The Contribution of Women on Boards of Directors: Going beyond the Surface. Corporate Governance: An International Review, 18(2), 136-148. DOI: 10.1111/j.1467-8683.2010.00784.x

Ning, Y., Hu., X., \& Garza-Gómez, X. (2015). An empirical analysis of the impact of large changes in institutional ownership on CEO compensation risk. Journal of Economics and Finance, 39(1), 23-47. DOI: 10.1007/s12197-012-9236-9

O’Reilly, C. A., \& Main, B. G. M. (2010). Economic and psychological perspectives on CEO compensation: A review and synthesis. Industrial and Corporate Change, 19(3), 675712. DOI: $10.1093 /$ icc/dtp050 
O'Reilly, C. A., \& Main, B. G. (2012). Women in the boardroom: symbols or substance? Working paper No. 117, Rock Center for Corporate Governance at Stanford University.

Pattarin, A., Alon, I., \& Zhang, Z. (2011). Executive perks: Compensation and corporate performance in China. Asia Pacific Journal of Management, 28(2), 401-425. DOI: $10.1007 / \mathrm{s} 10490-009-9162-3$

Pucheta-Martínez, M. C., Bel-Oms, I., \& Olcina-Sempere, G. (2016). Female institutional directors on boards and firm value. Journal of Business Ethics, 1-21. DOI: $10.1007 / \mathrm{s} 10551-016-3265-9$

Pucheta-Martínez, M. C., \& García-Meca, E. (2014). Institutional investors on boards and audit committees and their effects on financial reporting quality. Corporate Governance: an International Review, 22(4), 347-363. DOI: 10.1111/corg.12070

Reddy, K., Abidin, S., \& You, L. (2015). Does corporate governance matter in determining CEO compensation in the publicly listed companies in New Zealand? An empirical investigation. Managerial Finance, 41(3), 301-327. DOI: 10.1108/MF-09-2013-0253

Sánchez-Marín, G., Baixauli-Soler, J. S., \& Lucas-Pérez, M. E. (2011). Ownership structure and board effectiveness as determinants of TMT compensation in Spanish listed firms. Journal of Business Economics and Management, 12(1), 92-109. DOI: $10.3846 / 16111699.2011 .555371$

Sanders, W. G., \& Carpenter, M. A. (1998). Internationalization and firm governance: The roles of CEO compensation, top team composition, and board structure. Academy of Management Journal, 41(2), 158-179. DOI: 10.2307/257100

Shin, J. Y., \& Seo, J. (2011). Less pay and more sensitivity? Institutional investor heterogeneity and CEO pay. Journal of Management, 37(6), 1719-1746.

Shleifer, A., \& Vishny, R. W. (1997). A survey of corporate governance. The Journal of Finance, 52(2), 737-783. DOI: 10.1111/j.1540-6261.1997.tb04820.x

Spraggon, M., \& Bodolica, V. (2011). Post-acquisition structuring of CEO pay packages: Incentives and punishments. Strategic Organization, 9(3) 187-221.

Tajfel, H. (1982). Social psychology of intergroup relations. Annual Review of Psychology, 33, 1-39.

Tajfel, H., \& Turner, J. C. (2004). The social identity theory of intergroup behavior. In Political psychology: Key readings (pp. 276-293). New York, NY, US: Psychology Press. 
Terjesen, S., Sealy, R., \& Singh, V. (2009). Women directors on corporate boards: A review and research agenda. Corporate Governance: An International Review, 17(3), 320337. DOI: 10.1111/j.1467-8683.2009.00742.x

Tihanyi, L., Johnson, R., Hoskisson, R., \& Hitt, M. (2003) Institutional ownership differences and international diversification: The effects of boards of directors and technological opportunity. Academy of Management Journal, 46(2), 195-211. DOI: $10.2307 / 30040614$

Tosi H. L., Werner, S., Katz, J., \& Gomez-Mejia, L. R. (2000). How much does performance matter? A meta-analysis of CEO pay studies. Journal Management, 26(2), 301-339.

Trinidad, C., \& Normore, A. H. (2005). Leadership and gender: A dangerous liaison?. Leadership \& Organization Development Journal, 26(7), 574-590. DOI: $10.1108 / 01437730510624601$

Unified Code of Corporate Governance (CUBG). 2006. Informe del grupo especial de trabajo sobre buen gobierno de las sociedades cotizadas, Comité Conthe. Madrid.

Van Pelt, T. (2013). The effect of board characteristics on dividend policy. Tilburg: Tilburg University.

Wellalage, N. H., \& Locke, S. (2013). Women on board, firm financial performance and agency costs. Asian Journal of Business Ethics, 2(2), 113-127. DOI: 10.1007/s13520012-0020-x 
AW\#17-27-1

Table 1

Variable description

\begin{tabular}{|c|c|}
\hline Variables & Description \\
\hline CEO_COMP & Natural logarithm of CEO total compensation \\
\hline INST_WOM & Proportion of institutional female directors on board \\
\hline SENSIT_WOM & $\begin{array}{l}\text { Proportion of the board female directors who are representative of pressure-sensitive } \\
\text { institutional investors }\end{array}$ \\
\hline RESIST_WOM & $\begin{array}{l}\text { Proportion of the board female directors who are representative of pressure-resistant } \\
\text { institutional investors }\end{array}$ \\
\hline CEO_DÜALITY & $\begin{array}{l}\text { Dummy variable equals to } 1 \text { if the same person serves simultaneously as CEO and President } \\
\text { of the board and zero, otherwise }\end{array}$ \\
\hline CEO_TENURE & Number of years the CEO has held the firm's top ranking position \\
\hline INDP & $\begin{array}{l}\text { Ratio between the total number of independent directors on board and the total number of } \\
\text { directors on board }\end{array}$ \\
\hline OWNMAN & Proportion of stocks held by directors \\
\hline ROA & Operate income before interests and taxes over total assets \\
\hline SIZE & Natural logarithm of total assets \\
\hline LEV & Ratio of book debt to total assets \\
\hline $\begin{array}{l}\text { DUM_FEM_SEN } \\
\text { SIT }\end{array}$ & $\begin{array}{l}\text { The multiplication of a female dummy variable with a dummy variable representing } \\
\text { pressure-sensitive female directors }\end{array}$ \\
\hline $\begin{array}{l}\text { DUM_FEM_RES } \\
\text { IST }\end{array}$ & $\begin{array}{l}\text { The multiplication of a female dummy variable with a dummy variable representing } \\
\text { pressure-resistant female directors }\end{array}$ \\
\hline
\end{tabular}


Table 2

Main Descriptive Statistics

\section{Panel A. Continuous variables}

\begin{tabular}{lcccccc}
\hline \multicolumn{1}{c}{ Variables } & N & Mean & Median & Std. Dev. & Perc. 10 & Perc. 90 \\
\hline CEO_COMP & 553 & 4.252 & 5.537 & 3.184 & 0.000 & 7.711 \\
INST_WOM & 553 & $7.854 \%$ & $0.000 \%$ & $8.398 \%$ & $0.000 \%$ & $16.667 \%$ \\
SENSIT_WOM & 553 & $2.590 \%$ & $0.000 \%$ & $3.326 \%$ & $0.000 \%$ & $7.130 \%$ \\
RESIST_WOM & 553 & $5.264 \%$ & $0.000 \%$ & $8.009 \%$ & $0.000 \%$ & $14.286 \%$ \\
CEO_TENURE & 553 & 1.714 & 1.000 & 1.514 & 0.000 & 4.000 \\
INDP & 553 & $33.379 \%$ & $33.334 \%$ & $18.511 \%$ & $11.111 \%$ & $60.000 \%$ \\
OWNMAN & 553 & $27.726 \%$ & $21.193 \%$ & $27.578 \%$ & $0.032 \%$ & $66.900 \%$ \\
ROA & 553 & $-1.445 \%$ & $1.584 \%$ & $55.683 \%$ & $-16.207 \%$ & $14.533 \%$ \\
SIZE & 553 & 13.053 & 13.059 & 2.095 & 10.608 & 15.685 \\
LEV & 553 & $57.334 \%$ & $54.149 \%$ & $46.810 \%$ & $9.404 \%$ & $91.554 \%$ \\
\hline
\end{tabular}

Panel B. Dummies variables

\begin{tabular}{lcc}
\hline & $\mathbf{\% ( 0 )}$ & $\mathbf{\% ( 1 )}$ \\
\hline CEO_DUALITY & $68 \%$ & $32 \%$ \\
DUM_FEM_SENSIT & $95.48 \%$ & $4.52 \%$ \\
DUM_FEM_RESIST & $69.44 \%$ & $30.56 \%$
\end{tabular}

Mean, median, standard deviation, and percentiles of the main variables. Panel A and B show the continuous and dummy variables, respectively. 
Table 3

Results of the regression for institutional, pressure-sensitive and pressure-resistant female directors sit on the board of directors

\begin{tabular}{|c|c|c|c|c|}
\hline & $\begin{array}{l}\text { Expected } \\
\text { sign }\end{array}$ & $\begin{array}{c}\text { Model } 1 \\
\text { Estimated } \\
\text { coefficient } \\
\text { (p-value) }\end{array}$ & $\begin{array}{c}\text { Model } 2 \\
\text { Estimated } \\
\text { coefficient } \\
\text { (p-value) }\end{array}$ & $\begin{array}{c}\text { Model } 3 \\
\text { Estimated } \\
\text { coefficient } \\
\text { (p-value) }\end{array}$ \\
\hline INST_WOM_BD & - & $\begin{array}{c}-2.957 * * \\
(0.030)\end{array}$ & & \\
\hline INST_WOM_BD ${ }^{2}$ & + & $\begin{array}{c}19.786 * * * \\
(0.000)\end{array}$ & & \\
\hline SENSIT_WOM_BD & + & & $\begin{array}{l}-3.710 \\
(0.798)\end{array}$ & \\
\hline SENSIT_WOM_BD ${ }^{2}$ & - & & $\begin{array}{c}5.355 \\
(0.829)\end{array}$ & \\
\hline RESIST_WOM_BD & - & & & $\begin{array}{c}-10.803 * \\
(0.096)\end{array}$ \\
\hline RESIST_WOM_BD ${ }^{2}$ & + & & & $\begin{array}{c}43.726 * * \\
(0.022)\end{array}$ \\
\hline CEO_DUALITY & + & $\begin{array}{c}1.359 * * * \\
(0.000)\end{array}$ & $\begin{array}{c}1.235 * * * \\
(0.006)\end{array}$ & $\begin{array}{l}1.104 * * \\
(0.021)\end{array}$ \\
\hline CEO_TENURE & + & $\begin{array}{c}1.039 * * * \\
(0.000)\end{array}$ & $\begin{array}{c}1.186 * * * \\
(0.005)\end{array}$ & $\begin{array}{c}1.192 * * * \\
(0.005)\end{array}$ \\
\hline INDP & - & $\begin{array}{l}-0.197 \\
(0.593)\end{array}$ & $\begin{array}{c}0.217 \\
(0.606)\end{array}$ & $\begin{array}{c}0.039 \\
(0.921)\end{array}$ \\
\hline OWNMAN & + & $\begin{array}{c}0.009 * * * \\
(0.000)\end{array}$ & $\begin{array}{l}0.005^{*} \\
(0.080)\end{array}$ & $\begin{array}{c}0.008 * * \\
(0.017)\end{array}$ \\
\hline ROA & + & $\begin{array}{c}0.027 \\
(0.801)\end{array}$ & $\begin{array}{c}0.022 \\
(0.855)\end{array}$ & $\begin{array}{c}0.016 \\
(0892)\end{array}$ \\
\hline SIZE & + & $\begin{array}{c}0.625 * * * \\
(0.000)\end{array}$ & $\begin{array}{c}0.563 * * * \\
(0.000)\end{array}$ & $\begin{array}{c}0.595 * * * \\
(0.000)\end{array}$ \\
\hline LEV & + & $\begin{array}{c}0.514 * * * \\
(0.001)\end{array}$ & $\begin{array}{c}0.599 * * \\
(0.016)\end{array}$ & $\begin{array}{c}0.577 * * \\
(0.014)\end{array}$ \\
\hline DUM_FEM_SENSIT & $+/-$ & & $\begin{array}{c}1.745 \\
(0.139)\end{array}$ & \\
\hline DUM_FEM_RESIST & $+/-$ & & & $\begin{array}{c}0.323 \\
(0.500)\end{array}$ \\
\hline $\begin{array}{l}\text { Observations } \\
\mathrm{R}^{2}\end{array}$ & & $\begin{array}{c}553 \\
64.82 \%\end{array}$ & $\begin{array}{c}553 \\
65.24 \%\end{array}$ & $\begin{array}{c}553 \\
65.68 \%\end{array}$ \\
\hline \multicolumn{5}{|c|}{$\begin{array}{l}\text { Estimated coefficients ( } p \text {-value). CEO_PAY is the natural logarithm of CEO total compensation; INST_WOM_BD is the } \\
\text { proportion of institutional female directors on board; SENSIT_WOM_BD is the proportion of the board female directors } \\
\text { who are representative of pressure-sensitive institutional investors; RESIST_WOM_BD is the proportion of the board female } \\
\text { directors who are representative of pressure-resistant institutional investors; CEO_DUALITY equals to } 1 \text { if the same person } \\
\text { serves simultaneously as CEO and President of the board and } 0 \text {, otherwise; CEO_TENURE is the number of years the CEO } \\
\text { has held the firm's top ranking position; INDP_BD is the proportion of independent directors on board; OWNMAN is the } \\
\text { proportion of stocks held by directors; ROA is the operate income before interests and taxes over total assets; FIRM_SIZE is } \\
\text { the natural logarithm of total assets and LEV is the ratio of book debt to total assets. Significant at *** for } 99 \text { percent } \\
\text { confidence level, ** for } 95 \text { percent and * for } 90 \text { percent. }\end{array}$} \\
\hline
\end{tabular}

